\title{
Otpremnine u članicama EU-a
}

UDK: 349.2(4-67 EU)

doi: 10.3935/rsp.v28i2.1809

U tekstu se izlažu novija obilježja sustava otpremnina u članicama EU-a, a kao izvori koriste se mrežne stranice Eurofounda i Međunarodne organizacije rada. Razmjerno je teško precizno sistematizirati, klasificirati i uspoređivati nacionalne sustave otpremnina, s obzirom da države imaju različite tradicije i odnose u pogledu isplata radnicima po prestanku ugovora o radu. Sustavi otpremnina imaju različite namjene: primjerice, materijalno naknađuju radnike u slučaju otkaza ugovora o radu, uvjetovanog nekim posebnim razlozima, načinima ili brojem zaposlenih radnika, ili jednostavno naknađuju u slučaju bilo kojeg drugog oblika prestanka ugovora o radu. Stoga se sistematizacija i klasifikacija može osnivati na pravnom izvoru za pravo na otpremninu. U tom smislu, Tablica 1. sadrži pregled pravnih temelja za odobravanje prava na otpremninu u državama članicama EU-a.

U EU 23 države članice imaju nacionalni sustav otpremnina koji se temelji na zakonskom uređenju i propisivanju. U četiri države članice EU-a - Češkoj, Malti, Rumunjskoj i Švedskoj pravo na otpremninu proizlazi iz uređenja kolektivnim ugovorima. Tako ne postoji niti jedna država članica EU-a koja nema nacionalni sustav otpremnina sveobuhvatan preko cijelog gospodarstva. Potrebno je ipak podsjetiti kako je svako sistematiziranje i klasificiranje u značajnoj mjeri podložno proizvoljnošću. Primjerice, njemačko radno zakonodavstvo ne jamči pravo na otpremninu, odnosno potraživanja radnika tim temeljem. No, Zakon koji uređuje zaštitu kod otkazivanja ugovora o radu (njem. Kündigungsschutzgesetz), uvodi i uređuje pravo na novčani iznos u slučaju otkazivanja ugovora o radu iz gospodarskih razloga. Važno obilježje svakog nacionalnog sustava otpremnina jest definicija i razine naknade, pri čemu postoji gotovo opća uvjetovanost da se otpremnina određuje trajanjem staža radnika kod poslodavca i razlogom prestanka ugovora o radu.

\section{PREGLED PO DRŽAVAMA}

Većina država koje zakonski uređuju pravo na otpremninu uvjetuju samu primjenu prava na otpremninu i isplatu otpremnine minimalnim stažem, odnosno postavljaju uvjet minimalnog trajanja staža kod poslodavca kao uvjet za isplatu otpremnine. Gotovo u svim zemljama, nacionalni sustavi

Tablica 1.

Pravni temelj na otpremninu u državama članicama EU-a

\begin{tabular}{ll}
\hline Zakonsko uređenje prava na otpremninu & $\begin{array}{l}\text { Pravo na otpremninu uređeno } \\
\text { kolektivnim ugovorima }\end{array}$ \\
\hline $\begin{array}{l}\text { Austrija, Belgija, Bugarska, Cipar, Danska, Estonija, Finska, } \\
\text { Francuska, Grčka, Hrvatska, Irska, Italija, Latvija, Litva, } \\
\text { Luksemburg, Mađarska, Njemačka, Nizozemska, Portugal, }\end{array}$ & Češka, Malta, Rumunjska, Švedska \\
Poljska, Slovačka Republika, Slovenija, Španjolska & \\
\hline
\end{tabular}

Izvor: Eurofound i Međunarodna organizacija rada. 
otpremnina temelje se na financiranju od strane poslodavaca, što može predstavljati ozbiljan problem za likvidnost tvrtke ako se radi o zbrinjavanju većeg broja radnika. U nekim, pak, državama (pogledati npr. u daljnjem tekstu stanje u Republici Austriji), nacionalni se sustavi otpremnina financiraju namjenskim doprinosima. Ovdje razina izdašnosti otpremnine ovisi o akumuliranim doprinosima i na to ostvarenoj kamati, a financiranje se provodi kroz financijske institucije koje su zadužene za vođenje individualnih računa na kojima su sredstva uložena u tržište kapitala. U daljnjem tekstu iznose se obilježja sustava otpremnina u odabranim zemljama.

\section{Austrija}

Postoje dva sustava obvezne isplate otpremnina. Jedan se primjenjuje na ugovore o radu koji su započeli prije 2003. (njem. Abfertigung Alt; stari sustav) a drugi se odnosi na ugovore o radu koji su sklopljeni 2003. i kasnije (njem. Abfertigung Neu; novi sustav). Do kraja 2012. postojao je i mješoviti sustav. Prema starom sustavu, zaposlenik je po prekidu zaposlenja i uz određene uvjete imao pravo od svog poslodavca dobiti otpremninu u iznosu do 12 mjesečnih plaća koja ovisi o dužini radnog staža s tim poslodavcem. Čak i za ugovore o radu sklopljene prije 2003., poslodavac i zaposlenik mogu se suglasiti u pisanom obliku o prelasku na novi sustav, što vrijedi od dana potpisivanja suglasnosti. Tada poslodavac u ime zaposlenika uplaćuje doprinos za otpremninu (njem. Abfertigungsbeiträge) u iznosu od $1,53 \%$ bruto plaće zaposlenika u posebni fond za osiguranje radnika. Prema starom sustavu, osoba ima pravo na otpremninu, pri čemu u trenutku prekida radnog odnosa korisnik mora imati najmanje 3 godine radnog staža (odnosno 36 mjeseci uplaćivanja doprinosa) te mora dobiti otkaz od strane poslodavca bez svoje krivice. Nadalje, može se raditi o prijevre- menom prekidu radnog odnosa iz opravdanih razloga, sporazumnom prekidu radnog odnosa, a otpremnina se može ostvariti i po isteku određenog razdoblja u slučaju rada na određeno vrijeme. Raniji sustav je tradicionalni u kojemu poslodavac odgovara za otpremnine vlastitim radnicima ovisno o tome koliko su proveli kod njega. Takav sustav smanjuje mobilnost radnika među različitim tvrtkama jer prava nisu prenosiva, dovodi u opasnost mikro i manje poslodavce da u slučaju ekonomskih teškoća, otpremnine dodatno ugrožavaju opstanak poduzeća. Ujedno, takav sustav dovodi u nezavidan položaj i radnike jer postoji mogućnost da neće moći naplatiti otpremninu od mikro i malih poslodavaca i/ili će ući u sustav naplate iz stečaja, za razliku od radnika u javnoj službi koji nemaju te prijetnje. Zbog toga je za privatne poslodavce omogućen novi sustav obveznog osiguranja u kojem poslodavci uplaćuju mjesečne doprinose u zajednički fond, iz kojeg zaposlenici mogu ostvariti pravo na otpremninu bez da opterećuju likvidnost poslodavca u teškoćama koji mora otpuštati radnike. Radnici ne moraju brinuti hoće li ih mikro i mali poslodavac uopće moći isplatiti. Ako radnik prijeđe od jednog poslodavca drugom, prenosi akumulirana sredstva sa sobom, pa bi se takav sustav osiguranja za otpremnine mogao uvjetno nazvati drugim stupom osiguranja za nezaposlenost. Novi sustav obuhvaća sve zaposlene u privatnom sektoru, ali ne i javne službenike i namještenike, a razvijen je i poseban model za zaposlene u poljoprivredi. Prema važećim propisima, nakon prestanka ugovora o radu, radnik ima pravo na otpremninu iz fonda, osim ako je sam podnio zahtjev za otkaz, ako je poslodavac donio odluku o otkazu zbog nezakonitog ponašanja radnika i ako su doprinosi uplaćivani u fond manje od tri godine. Iznos otpremnine izračunava se na temelju akumuliranih doprinosa do kraja mjeseca kada pravo dospijeva. 


\section{Belgija}

U slučaju pojedinačnog viška, poslodavac i otpušteni radnik mogu birati između otkaznog roka tijekom kojeg ugovor o radu još uvijek traje i otpremnine kojom se odmah prekida ugovor o radu. U potonjem slučaju, otpremnina je jednaka plaći i naknadama pomnoženim sa zakonskim trajanjem otkaznog roka. U slučaju kolektivnih otkaza, otpušteni radnici osim naknade za vrijeme nezaposlenosti, imaju pravo i na posebnu otpremninu. Iznos otpremnine jednak je polovici razlike između radnikove neto plaće i iznosa naknade za nezaposlene koju osoba prima, pri čemu je najveći određeni iznos bruto plaće $3145 €$. Zaposlenik ima pravo na četiri mjeseca otpremnine, počevši od dana prestanka njegova ugovora o radu ili nakon isteka otkaznog roka. Neke skupine zaposlenika nemaju pravo na otpremnine, poput zaposlenih u graditeljstvu te lučkih i brodskih radnika. Za potrebe izračunavanja posebne odštete, zakon određuje da se radi o kolektivnom otpuštanju ukoliko je tijekom bilo kojeg razdoblja od 60 dana poslana obavijest o raskidu šestorici ili više radnika u poduzeću koje zapošljava između 20 i 59 ljudi i $10 \%$ ili više radne snage u poduzeću koje zapošljava 60 ili više ljudi. Otpremnina ne postoji tijekom probnog razdoblja. U slučaju prekida ugovora na određeno vrijeme, otpremnina je jednaka iznosu plaće koju bi radnik dobio da je ostao raditi do kraja ugovora. Ipak, taj iznos ne smije biti veći od dvostrukog iznosa plaće koja bi se ostvarila za vrijeme trajanja otkaznog roka kod ugovora o radu na neodređeno vrijeme.

\section{Bugarska}

Nema zakonskog određenja otpremnine, osim u dva slučaja. Prvi je nakon prestanka radnog odnosa zbog bolesti za zaposlenika koji ima najmanje 5 godina radnog staža. Tada se ostvaruje pravo na otpremninu u vrijednosti dvije bruto mjesečne plaće. Drugi slučaj je nakon prestanka radnog odnosa pošto je zaposlenik stekao pravo na mirovinu. Tada dobiva otpremninu u vrijednosti dvije mjesečne plaće ili 6 mjesečnih plaća ako je radio kod poslodavca više od 10 godina. Kod otpuštanja zbog viška radne snage, otpremnina je jednaka iznosu jednomjesečne plaće uslijed pojedinačnog ili kolektivnog otkaza zbog ekonomskih razloga.

\section{Cipar}

Zaposlenik koji je otpušten kao višak radne snage ima pravo na otpremninu pod uvjetom da ima neprekidni radni staž od najmanje 104 tjedna. Otpremnina se isplaćuje iz Fonda za otpremninu koji se u potpunosti financira doprinosima poslodavaca od 1,2\% na bruto plaću zaposlenika. Otpremnina se izračunava na sljedeći način: iznos dvotjedne plaće za svaku godinu do četiri godine radnog staža; plaća za 2,5 tjedana za svaku godinu od 5 do 10 godina radnog staža; trotjedna plaća za svaku godinu od 11 do 15 godina radnog staža; plaća za 3,5 tjedna za svaku godinu od 16 do 20 godina radnog staža i četverotjedna plaća za svaku godinu iznad 20 godina radnog staža. Iznos otpremnine u 2019. bio je ograničen na $52883 €$, dok je do 2018. iznosio $52663 €$. Ukoliko je otkaz uzrokovan neodgovarajućim ponašanjem zaposlenika, zaposlenik nema pravo na otpremninu.

\section{Češka}

Trenutno nema zakonske otpremnine. Otpremnina je postojala do izmjena $\mathrm{i}$ dopuna Zakona u 2012. Prema tadašnjim propisima, ako je zaposlenje trajalo manje od godine dana, zaposlenici su imali pravo na otpremninu u iznosu od njihove jedne prosječne mjesečne plaće. Ako je zaposlenje trajalo više od godine, ali manje od dvije godine, zaposlenici su imali pravo na dvije prosječne mjesečne plaće, a za više od dvije godine radnog staža, otpremnina je bila u vrijednosti tri prosječne mjesečne plaće. Nije bilo prava na otpremninu ako je 
otkaz bio uvjetovan ponašanjem ili neradom zaposlenika.

\section{Danska}

Stručni radnici (bijeli ovratnici) koji imaju do 12, 15 ili 18 godina radnog staža $\mathrm{u}$ istom poduzeću u slučaju otkaza dobivaju otpremninu u vrijednosti jedne, dvije i tri mjesečne plaće. Jednaka su pravila za individualni i kolektivni otkaz. Proizvodni radnici (plavi ovratnici) nemaju zakonom propisane otpremnine nego je ona utvrđena kolektivnim ugovorima.

\section{Estonija}

Nakon prestanka radnog odnosa zbog toga što je proglašen viškom, zaposlenik ima pravo na otpremninu u iznosu svoje prosječne mjesečne plaće. Ako je riječ o otkazu koji nije uvjetovan ekonomskim razlozima, ne postoji pravo na otpremninu. U slučaju prekida ugovora o radu na određeno vrijeme zato što je zaposlenik proglašen viškom, poslodavac mora platiti otpremninu koja odgovara iznosu plaće što bi je zaposlenik dobio do završetka trajanja ugovora. Ako je ugovor poništen zbog više sile, nema prava na otpremninu. Ako je poslodavac zakasnio s davanjem obavijesti o otkazu s obzirom na rok utvrđen zakonom ili kolektivnim ugovorom, zaposlenik ima pravo na otpremninu u iznosu koju bi imao da je poslodavac najavio u odgovarajućem otkaznom roku. Ako poslodavac želi odmah prekinuti radni odnos, zaposlenik može tražiti uvećani iznos otpremnine. Zaposlenici koji su radili kod istog poslodavca od 5 do 10 godina imaju pravo na dodatnu naknadu u iznosu jednomjesečne plaće koju isplaćuje Fond za osiguranje za vrijeme nezaposlenosti (est. Töötukassa). Zaposlenici koji su radili kod istog poslodavca više od 10 godina imaju pravo na dodatnu naknadu u iznosu dvomjesečne plaće koju isplaćuje navedeni Fond. To vrijedi za slučajeve individualnih i kolektivnih otkaza. Prema istraživanju provedenom
2013., 82\%-92\% onih koji su proglašeni viškom procjenjuje kako je iznos otpremnine bio zadovoljavajući. U cjelini, otpremnine su prilično visoke i predstavljaju pristojan dohodak za osobe koje su ostale bez posla zbog toga što su proglašene viškom.

\section{Finska}

Državni dužnosnici imaju pravo na otpremninu ukoliko im zavod za zapošljavanje ne može naći drugi posao ili program osposobljavanja u roku od mjesec dana nakon prekida radnog odnosa. Osoba mora biti u dobi između 45 i 64 godine, zaposlena u državnoj službi najmanje pet uzastopnih godina s prosječnim tjednim radnim vremenom od najmanje 16 sati i ne smije imati pravo na mirovinu. Otpremnine nisu formalno regulirane za bilo koje druge vrste poslodavaca ili ugovora. Poslodavci koji zapošljavaju najmanje 30 radnika moraju osigurati besplatno stručno osposobljavanje ili tečajeve za radnike kojima su otkazali ugovor iz ekonomskih razloga i koji su za njih radili najmanje 5 godina. Od tog se prava može odustati kolektivnim ugovorom.

\section{Francuska}

Prema važećem Zakonu o radu iz 2017., zaposlenici s najmanje 8 mjeseci radnog iskustva (ranije je bilo 12 mjeseci) kod istog poslodavca i ugovorom o radu na neodređeno vrijeme imaju pravo na otpremninu u slučaju otkaza zbog gospodarskih ili osobnih razloga. Ukoliko je otkaz uslijedio zbog grube greške ili nedoličnog ponašanja zaposlenika (franc. faute grave), kao i kod namjernog izazivanja štete (franc. faute lourde), ne ostvaruje se pravo na otpremninu. Zakon samo određuje najmanji iznos otpremnine, tako da ona iznosi najmanje četvrtinu plaće pomnoženu s brojem godina staža za osobe koje rade do 10 godina, trećinu plaće pomnoženu s brojem godina staža za osobe koje rade 11 i više godina. Pritom se za izračun plaće uzima prosjek 
primanja posljednjih 12 mjeseci, a također ovisi je li zaposlenik radio puno ili skraćeno radno vrijeme. Pravo na otpremninu imaju samo zaposleni s ugovorima na neodređeno vrijeme, a radnici s ugovorima na određeno vrijeme mogu po završetku trajanja ugovora primiti naknadu za prekarijat. Kolektivnim ugovorima i/ili ugovorom o radu mogu biti omogućeni veći iznosi otpremnina i neka druga prava. Francuska je specifična, jer se otpremnina razlikuje od naknade za neopravdani otkaz. Dok se iznos otpremnine obračunava na temelju bruto plaće i godina radnog staža prije prekida ugovora o radu, odluku o naknadi za neopravdani otkaz donosi sud uzimajući u obzir štetu koja je nastala zaposleniku.

\section{Grčka}

Iznos otpremnine ponajviše ovisi o duljini radnog staža kod poslodavca i udvostručuje se ako poslodavac ne poštuje zakonski otkazni rok. Do godine dana radnog staža nema otpremnine, od 1 do 4 godine staža otpremnina je jednaka 1 mjesečnoj plaći ako poslodavac poštuje zakonski otkazni rok; pa sve do 6 mjeseci za 16 i više godina radnog staža. Za proizvodne radnike (plave ovratnike), iznos otpremnina razlikuje se ovisno o trajanju radnog staža te odgovara plaći od 5 dana do 165 dana, bez obzira poštuje li poslodavac zakonski otkazni rok, odnosno otkazuje li poslodavac bez prethodne obavijesti. Od srpnja 2019., poslodavci moraju platiti otpremninu na bankovne račune zaposlenika i pripadajući porez putem doznake umjesto da koriste bankovni ček. Novi zakon također navodi da se rokovi za podnošenje zahtjeva za otpremninu (tri i šest mjeseci od datuma otkaza) mogu obustaviti ako zaposlenik podnese predstavku inspekciji rada ili pokrene postupak mirenja pa se rok produžuje do okončanja postupka i donošenja odgovarajuce odluke. Od kolovoza 2019. poslodavac nije dužan navesti razlog za prestanak radnog odnosa.

\section{Irska}

Zaposlenik ostvaruje pravo na otpremninu ako ima najmanje 104 tjedna staža neprekidnog radnog odnosa, stariji je od 16 godina i ako je osiguran u skladu sa zakonom (eng. The Social Welfare Consolidation Act iz 1993.), a njegov je otkaz posljedica viška radnika. Zaposlenici koji su višak radne snage imaju pravo na otpremninu $u$ iznosu dvotjedne bruto plaće za svaku godinu radnog staža uvećanu za jednu tjednu plaću. Najveći iznos otpremnine je $600 €$ tjedno. Zakonom određene otpremnine ne podliježu oporezivanju, a na svaki iznos iznad zakonskog minimuma plaća se porez. Ako je tvrtka likvidirana i ne može isplatiti otpremninu, radnik ju dobiva od Fonda za socijalno osiguranje. Poslodavci mogu ugovoriti veće iznose otpremnine od onih utvrđenih zakonom, obično u vrijednosti između dva do sedam tjedana plaće po godini rada, što može, ali i ne mora, biti dodatak zakonski utvrđenoj otpremnini. U javnom sektoru, uobičajeni iznos otpremnine jednak je vrijednosti plaće za pet tjedana, odnosno trotjednoj plaći uvećanoj za zakonsku otpremninu u vrijednosti dvotjedne plaće.

\section{Italija}

Talijanski sustav otpremnina ima niz posebnosti i ustvari dva najvažnija oblika. Međutim, moglo bi se reći kako u Italiji ne postoji model otpremnina u konvencionalnom smislu. Talijanska dva sustava ne spadaju u klasične kategorije otpremnina koje su poznate u drugim zemljama. Prvi model (tal. tutela obbligatoria) omogućava naknadu osobama koje su otpuštene bez svoje krivnje, pri čemu se razlikuju tvrtke s 15 ili manje zaposlenih i one sa 16 ili više. Drugi model je Trattamento di fine rapporto (TFR), koji je dio radnikove plaće čije se plaćanje odgađa do prekida radnog odnosa. Stoga se ne može smatrati uobičajenom naknadom jer predstavlja određeni dio plaće koja se ne isplaćuje. TFR se računa tako što se plaća za 
cijelu godinu dijeli s 13,5 , uvećano za $1,5 \%$ za svaku godinu radnog staža i za stopu inflacije. TFR se mora isplatiti radniku po završetku radnog odnosa i na njega ne utječe razlog prekida, osim u slučajevima kada se u potpunosti prenosi kao uplata za dopunsko mirovinsko osiguranje. Zakonom su predviđene mogućnosti djelomičnog korištenja TFR-a tijekom radnog odnosa. Zakonom iz 2004. (tal. Legge 243/2004), TFR se može koristiti za financiranje dopunskog mirovinskog osiguranja, koje je nadopuna javnog mirovinskog sustava međugeneracijske solidarnosti. Tako radnik može odabrati želi li primati TFR po završetku radnog odnosa ili kao mirovinu iz dopunskog mirovinskog osiguranja. Zakonske promjene broj 124 od 4. kolovoza 2017. omogućile su da radnici mogu podijeliti TFR sredstva između fonda u kompaniji i mirovinskog fonda te zahtijevati prijevremenu isplatu iz mirovinskog fonda u slučaju nezaposlenosti koja traje duže od 24 mjeseca.

\section{Latvija}

Zaposlenik ima pravo na otpremninu ukoliko je proglašen viškom. Ako kolektivnim ugovorom ili ugovorom o radu nije određen veći iznos otpremnine, poslodavac mora isplatiti otpremninu u vrijednosti prosječne mjesečne plaće ako zaposlenik radi kod poslodavca manje od 5 godina; dvije prosječne mjesečne plaće za rad 5 do 10 godina; tri prosječne mjesečne plaće za 10 do 20 godina i četiri prosječne mjesečne plaće za više od 20 godina. Prosječna se plaća računa kao prosjek redovite plaće i dodataka u posljednjih šest mjeseci.

\section{Litva}

Pravo na i iznos otpremnine ovise o razlozima otkaza, dužini radnog staža, vrsti ugovora i drugim čimbenicima. Prilikom prekida ugovora o radu na opravdanu inicijativu zaposlenika, poslodavac mora zaposleniku isplatiti otpremninu u iznosu njegove prosječne mjesečne plaće ako je radni odnos trajao manje od godinu dana, odnosno dvije plaće ako je trajao duže od godine dana. Ako je radni odnos prekinut na inicijativu poslodavca bez ikakve krivnje radnika, poslodavac mora zaposleniku isplatiti otpremninu u iznosu polovice njegove mjesečne place; ako je radni odnos trajao manje od godine dana, odnosno dvije plaće ako je trajao duže od godine dana. U slučaju nelikvidnosti poslodavca, u skladu sa Zakonom o jamstvu radničkih potraživanja, utvrđuje se postupak isplate otpremnina pri čemu se uzima $\mathrm{u}$ obzir trajanje zaposlenja na istom radnom mjestu. Uvjeti za pravo na otpremninu su najmanje pet godina neprekidnog radnog odnosa prije raskida ugovora o radu, s time da je poslodavac pokrenuo postupak za otkaz i nema nikakve zaposlenikove krivnje. Naknada se isplaćuje iz posebnog Fonda za pokriće potraživanja. Za zaposlenike koji su radili u ustanovama koje se financiraju iz proračuna i u Litvanskoj narodnoj banci, naknadu plaća njihov poslodavac. Fond za pokriće potraživanja isplaćuje otpremninu koja iznosi 77,58\% prosječne mjesečne plaće zaposlenika ako je radni staž kod poslodavca na dan otkaza bio od 5 do 10 godina; 77,58\% dvije prosječne mjesečne plaće ako je radni staž kod poslodavca bio od 10 do 20 godina i 77,58\% tri prosječne mjesečne plaće ako je radni staž kod poslodavca na dan otkaza bio 20 godina ili više. Prosječna plaća određuje se kao prosjek dohotka od radnog odnosa ostvarenog u prethodnih 12 mjeseci. Prema Zakonu o radu, čl. 59, poslodavac ima pravo otkazati ugovor o radu s otkaznim rokom tri radna dana $\mathrm{i}$ isplatom otpremnine u iznosu šest prosječnih plaća zaposlenika. Ova odredba ne odnosi se na državne i općinske institucije ili ustanove koje se financiraju iz državnog ili općinskog proračuna. Kod prekida ugovora o radu bez suglasnosti ugovorne stranke (čl. 60), zaposlenik ima pravo na otpremninu u visini svoje prosječne mjesečne plaće, a iznos se smanjuje na polovicu prosječne plaće ako radni odnos traje manje od jedne godine. 


\section{Luksemburg}

Otpušteni zaposlenik, osim u slučaju grubog kršenja zakona, ima pravo na otpremninu ako ima najmanje pet godina radnog staža u tvrtki. Zaposlenici imaju pravo na otpremninu i otkazni rok u skladu s ostvarenim radnim stažem. Za ostvareni staž ispod 5 godina nema otpremnine, za 5-10 godina radnog staža otpremnina je jednaka prosječnoj mjesečnoj plaći, za 10-15 godina je dvije prosječne mjesečne plaće, za 15-20 godina tri mjesečne plaće, a nakon toga su povećanja po tri mjeseca do ukupno dvanaest mjeseci za zaposlene s preko 30 godina staža. Iznos otpremnine izračunava se na temelju plaće koja se efektivno isplaćivala zaposleniku u prethodnih 12 mjeseci koji su neposredno prethodili otkazu. U plaće se uključuju naknade za vrijeme bolovanja, uobičajeni i ostali dodaci, ali se ne uključuju dodaci za prekovremeni rad, bonusi i povremeni dodaci. Poslodavac mora isplatiti otpremninu na kraju otkaznog roka, bez obzira je li dostavio obavijest o otkazu. Otpremnina ne podliježe porezu na dohodak ili plaćanju doprinosa za socijalno osiguranje. Poslodavci s manje od 20 zaposlenika mogu se odlučiti za duži otkazni rok u slučaju otpuštanja umjesto otpremnine, a to se odnosi na zaposlenike s radnim stažem dužim od pet godina koji su otpušteni iz ekonomskih razloga. Ti otkazni rokovi rastu za svakih 5 godina staža, od 5 mjeseci za one s 5-10 godina, sve do 18 mjeseci za one s preko 30 godina staža. Kolektivni ugovori mogu odrediti veće iznose otpremnina, kao što je napravljeno za bankarski sektor koji je važan sektor u Luksemburgu.

\section{Mađarska}

Zaposlenik ima pravo na otpremninu ako poslodavac prekine njegov radni odnos i ako poslodavac prestane poslovati, a nema pravnog sljednika. Za radnika koji ima do tri godine radnog staža iznos otpremnine jednak je plaći za mjesec dana; za radnika koji ima do pet godina radnog staža plaći za dva mjeseca; do 10 godina staža tri mjeseca; do 15 godina staža četiri mjeseca; do 20 godina staža pet mjeseci i za radnika koji ima do 25 godina radnog staža šest mjeseci. Iznos otpremnine povećava se za 1-3 mjesečne plaće ako se radni odnos prekine za radnika kojem još treba pet godina ili manje do starosne mirovine, pri čemu su nešto drugačiji uvjeti ako je osoba zaposlena u javnom sektoru. Zaposlenik nema pravo na otpremninu ako je u razdoblju dostavljanja obavijesti o otkazu otišao u mirovinu ili ako poslodavac koji je prestao poslovati nema pravnog sljednika; ako je razlog otkaza povezan s ponašanjem zaposlenika na radu ili je zaposlen na temelju ugovora na određeno vrijeme. Potrebno je naglasiti kako se kolektivnim ugovorima mogu odrediti i niži iznosi otpremnina od onih propisanih zakonom. Zakon ne određuje otpremnine kod kolektivnih otkaza.

\section{Malta}

Ne postoji zakonski određena otpremnina ili naknada koja ima funkciju otpremnine osim naknade koja se ostvaruje ako je osoba proglašena viškom radne snage. Ako se radi o višku radne snage kod ugovora na neodređeno vrijeme, zaposlenik nakon primitka obavijesti o prekidu ugovora ima mogućnost ili nastaviti raditi tijekom otkaznog roka ili tražiti od poslodavca da mu isplati iznos jednak polovini plaće koju bi ostvario da je radio tijekom preostalog razdoblja otkaznog roka. Ako poslodavac odluči da neće dopustiti zaposleniku da nastavi raditi tijekom otkaznog roka, poslodavac je dužan isplatiti zaposleniku iznos jednak punoj plaći koja bi se ostvarila u preostalom dijelu otkaznog roka.

\section{Nizozemska}

Obvezna otpremnina zove se »prijelazna naknada«. Prema prijašnjim pravilima koja su vrijedila do kraja 2019., zaposlenici su ispunjavali uvjete za otpremninu ako su radili 
kod poslodavca najmanje 24 mjeseca, a poslodavac im je otkazao ugovor o radu. Radni odnos prestaje na obostrani pristanak inicijativom poslodavca, kada poslodavac nije obnovio ugovor o radu na određeno vrijeme ili kada je radnik prekinuo radni odnos zbog nedoličnog ponašanja poslodavca. Iznos otpremnine je 1/6 mjesečne plaće zaposlenika za svako razdoblje od 6 mjeseci koje je zaposlenik radio kod poslodavca, uvećano za 1/6 mjesečne plaće za svako šestomjesečno razdoblje koje je radio više od 10 godina. Otpremnina ne može biti veća od $81000 €$ ili jedne godišnje plaće (ako je godišnja plaća veća od $81000 €)$. U poduzećima s više od 25 zaposlenih, otpremnina za zaposlenike koji su stariji od 50 godina i koji su kod poslodavca radili najmanje 10 godina, jednaka je polovici njihove mjesečne plaće za svako razdoblje od 6 mjeseci koje su radili za poslodavca. U posebnim okolnostima, na temelju načela pravednosti i uzimajući u obzir nemarno ponašanje poslodavca ili zaposlenika prije otkaza, sud može odlučiti povećati ili smanjiti iznos otpremnine. Kolektivnim ugovorom može se odrediti drugačije pravo na otpremninu. S obzirom na to da je izmijenjen nizozemski Zakon o zapošljavanju, od 1. siječnja 2020. ukida se uvjet da ugovor o radu mora trajati najmanje 24 mjeseca. To znači da zaposlenik ima pravo na otpremninu od početka ugovora o radu, u slučaju otkaza na inicijativu poslodavca. Promijenjen je i način izračuna prijelaznog plaćanja (otpremnine) koji se više ne obavlja za razdoblja od po šest mjeseci. Umjesto toga, prijelazno plaćanje za svaku kalendarsku godinu u kojoj je trajao ugovor o radu jednako je trećini mjesečne plaće i proporcionalnom dijelu za razdoblje kada je ugovor o radu trajao manje od kalendarske godine. Tijekom cijelog trajanja ugovora o radu prijelazna plaća stoga iznosi 1/3 mjesečne plaće po godini radnog staža.

\section{Njemačka}

Moraju biti ispunjeni brojni zahtjevi kako bi se zaposlenika otpustilo na zako- nit način. To često dovodi poslodavce $u$ složenu situaciju tako da su oni uglavnom skloni sa zaposlenicima sklopiti sporazum o nagodbi kako bi izbjegli pravni spor pred radnim sudom koji je prilično teško uvjeriti da je otkaz opravdan i/ili neophodan. Zbog toga, najveći dio zahtjeva poslodavca za prestanak radnog odnosa završi s nagodbom i isplatom otpremnine. U slučaju da je podjednaka vjerojatnost dobivanja spora, stranke se obično dogovore za iznos otpremnine od pola mjesečne plaće za svaku godinu radnog staža, pri čemu to nije nepromjenjivo i zakonski utvrđeno pravilo. Ako je velika vjerojatnost poslodavca da izgubi spor, tada obično pristaje na jednu mjesečnu plaću (a u posebnim slučajevima čak i na dvije) za svaku godinu radnog staža. Otpremnine su podložne oporezivanju kao svaki drugi oblik dohotka, a na njih se ne naplaćuju doprinosi za socijalno osiguranje. U većim i dobro stojećim tvrtkama koje provode restrukturiranje, zaposlenici mogu očekivati pozamašne otpremnine, $100000 €$ za 24 godine radnog staža za obične radnike i do $250000 €$ za djelatnike na višim položajima. Prema sadašnjim propisima, ako zaposlenik dobije otkaz zbog poslovnih razloga, može birati hoće li primiti zakonski zajamčenu otpremninu ili će tužiti poslodavca radnom sudu. Zajamčena otpremnina je pola mjesečne plaće po godini staža u poduzeću, a poslodavac je u takvom otkazu obavezan obrazložiti poslovni razlog te odluke i podsjetiti ga da sada ima tri tjedna vremena uložiti tužbu pred sudom. To znači da prihvaća otkaz bez parnice i da će mu biti isplaćena otpremnina u iznosu polovice mjesečne plaće za svaku godinu radnog staža. Najveći iznos otpremnine je 12 mjesečnih plaća, ali iznos može biti i veći ako se radi o starijem radniku. Nakon navršenih 50 godina života i 15 godina staža, otpremnina zbog otkaza bez valjanog razloga iznosi 15 mjesečnih plaća, a nakon 55 godina života i 20 godina rada iznosi 18 mjesečnih plaća. 


\section{Poljska}

Dan nakon isteka otkaznog roka zaposlenici imaju pravo na otpremninu u iznosu mjesečne plaće ako je staž bio kraći od dvije godine; dvije mjesečne plaće ako je staž bio od dvije do osam godina i tri mjesečne plaće ako je staž bio preko 8 godina. Iznos otpremnine ne može biti veći od 15 minimalnih plaća koje se određuju u posebnim odredbama. Otpremnine plaćaju poslodavci koji zapošljavaju najmanje 20 zaposlenika i to samo u dvije situacije. Prva je ako je riječ o kolektivnom otkazu tako da se u razdoblju od 30 dana otpušta najmanje 10 radnika u tvrtkama s 20-99 zaposlenih, najmanje 10\% radne snage u tvrtkama sa 100-299 zaposlenika ili najmanje 30 radnika u tvrtkama koje zapošljavaju više od 300 zaposlenika. Drugi slučaj je individualni prestanak radnog odnosa koji nije uzrokovan ponašanjem zaposlenika. Zaposlenici u tvrtkama koje zapošljavaju manje od 20 zaposlenika nemaju pravo na otpremninu. Ako je tvrtka likvidirana ili je u stečaju, likvidator ili službeni stečajni upravitelj dužan je isplatiti otpremninu od imovine tvrtke. Ako to nije moguće, otpušteni radnik mora se prijaviti u Jamstveni fond za pokriće radničkih potraživanja, za nadopunu financijskih sredstava koja nedostaju. U svakom slučaju, otpušteni radnik dobiva otpremninu.

\section{Portugal}

Otpremnine su u 2011. smanjene s 30 na 20 dana iznosa plaće po godini službe. Zakon iz 2013. dodatno je smanjio otpremnine na iznos od najviše 12 osnovnih plaća uz uvećanje za minuli radni staž ili 240 zakonskih minimalnih plaća (ili 18 osnovnih plaća uvećanih za radni staž u slučaju ugovora na određeno vrijeme ili privremenog ugovora). Kao rezultat ovih i prethodnih promjena, otpremnina se općenito temelji na tri različite formule za razdoblja službe prije, za vrijeme i nakon sljedećih datuma: ugovori o radu sklopljeni prije
1. studenog 2011., ugovori o radu sklopljeni između 1. studenog 2011. i 30. rujna 2013. i ugovori o radu sklopljeni nakon 1 . listopada 2013. Otpremnina ne može biti veća od 20 minimalnih nacionalnih plaća (700 € u studenom 2019.), u najvećem iznosu koji je jednak 12 osnovnih plaća uz uvećanje za minuli radni staž. To se odnosi na pojedinačne otkaze ugovora o radu i na kolektivna otpuštanja. Za djelomično financiranje otpremnina kod pojedinačnih i kolektivnih otkaza koriste se Kompenzacijski fond (port. Fundo de Compensação do Trabalho - FCT) i Jamstveni fond za pokrice radničkih potraživanja (port. Fundo de Garantia de Compensação do Trabalho - FGCT). Sredstva iz ta dva fonda imaju za cilj osigurati radniku pravo na polovicu naknade koja dospijeva u slučaju prestanka ugovora o radu. Poslodavci uplaćuju $1 \%$ plaće $(0,925 \%$ za FCT i $0,075 \%$ za FGCT) za zaposlene nakon 1. listopada 2013. Iznos naknade jednak je iznosu 20 dana osnovne plaće i dodatku za radni staž za svaku punu godinu staža ili njegov dio. Nove odredbe temelje se na tripartitnom sporazumu koji su u siječnju 2012. potpisali svi socijalni partneri, osim Generalne konfederacije portugalskih radnika (port. Confederação Geral dos Trabalhadores Portugueses CGTP-IN). Ove zakonske promjene imaju veću snagu od kolektivnih ugovora koji predviđaju veće iznose ili povoljnije definicije otpremnina.

\section{Rumunjska}

Zakon ne propisuje posebna pravila o otpremninama u slučaju individualnog ili kolektivnog otkaza. Izuzetak je pravilnik Vlade br. 36/2013, kojim je predviđeno pravo na otpremnine u pojedinim poduzećima u državnom vlasništvu. Poslodavac je obvezan na isplatu otpremnina ako je to sadržano u važećem kolektivnom ugovoru, a sam iznos otpremnine najčešće ovisi o dužini radnog staža zaposlenika. 


\section{Slovačka}

Ne postoji opće pravo na otpremninu, osim u slučaju otpuštanja kao višak radne snage. Donošenjem izmjena Zakona o radu iz 2012., stupanj prava zaposlenika ovisi o tome je li primio obavijest od poslodavca ili je sporazumno pristao na otkaz. Zakon o radu predviđa posebne otpremnine u slučajevima ako je zaposlenik kojem je radni odnos trajao najmanje dvadeset godina, zbog svog zdravstvenog stanja izgubio sposobnost obavljanja posla - na kraju radnog odnosa ima pravo na otpremninu u iznosu od četiri njegove prosječne mjesečne plaće (čl. 63). C̆l. 76 određuje da, ako poslodavac zaposleniku otkaže radni odnos ili sporazumnim prekidom zbog toga što zaposlenik više ne smije ili može obavljati svoj posao, zaposlenik ima pravo na otpremninu u iznosu od najmanje deset svojih mjesečnih plaća. Ovo se ne primjenjuje ako je nesreću na radu prouzročio zaposlenik svojom krivnjom.

\section{Slovenija}

Poslodavac koji iz poslovnog razloga otkaže ugovor o radu na neodređeno vrijeme (uključujući slučajeve kolektivnih otkaza, odnosno najmanje 10 radnika u tvrtkama s 21-99 zaposlenih, najmanje $10 \%$ u tvrtkama sa 100-299 zaposlenika ili 30 otkaza u većim firmama) dužan je radniku isplatiti otpremninu. Osnovica za obračun otpremnine je prosječna mjesečna plaća koju je radnik primio tijekom posljednja tri mjeseca prije otkaza. Radnik ima pravo na otpremninu u iznosu od jedne petine osnovice plaće za svaku godinu zaposlenja ako je kod poslodavca bio zaposlen između jedne i deset godina; jednu četvrtinu osnovice plaće za svaku godinu zaposlenja ako je kod poslodavca bio zaposlen od deset do dvadeset godina; trećinu osnovice plaće za duže od dvadeset godina. Iznos otpremnine ne može biti veći od iznosa desetostruke prosječne mjesečne plaće koju je radnik primio tijekom posljednja tri mjeseca prije otkaza, osim ako granskim kolektivnim ugovorom nije drugačije određeno. U postupku prisilne nagodbe radnik i poslodavac mogu se u pismenom obliku suglasiti o načinu i obliku isplate otpremnine ili umanjenju minimalnog zakonskog iznosa otpremnine ako bi zbog isplate otpremnine bio ugrožen opstanak većeg broja radnih mjesta u tvrtki. Poslodavac mora isplatiti otpremninu radniku do otkaza ugovora o radu, osim ako granskim kolektivnim ugovorom nije drugačije određeno. Radnik kojem je raskinut ugovor o radu na određeno vrijeme također ima pravo na otpremninu, osim u slučajevima kada je radnik zamjenjivao drugog privremeno odsutnog radnika, u jednoj kalendarskoj godini obavljao sezonske poslove manje od tri mjeseca ili sudjelovao u javnim radovima i/ili poslovima u okviru aktivne politike zapošljavanja. U slučaju prestanka ugovora o radu na određeno vrijeme sklopljenog na razdoblje od jedne godine ili manje, radnik ima pravo na otpremninu $u$ visini jedne petine osnovice plaće, odnosno prosječne mjesečne plaće radnika s punim radnim vremenom tijekom posljednja tri mjeseca prije raskida ugovora o radu. Ako je ugovor o radu na određeno vrijeme trajao duže od jedne godine, radnik ima pravo na otpremninu uvećanu za proporcionalni dio otpremnine za svaki mjesec rada, odnosno $1 / 5$ osnovice place $+1 / 12$ od $1 / 5$ osnovice plaće za svaki mjesec zaposlenja nakon jedne godine rada. Propis o otpremninama znatno je promijenjen posljednjim izmjenama Zakona o radnim odnosima iz 2013. U cilju smanjenja segmentacije na tržištu rada i ublažavanja razlika u troškovima rada različitih vrsta ugovora o radu, socijalni partneri su se dogovorili da će smanjiti otpremnine za stalno zaposlene i uvesti otpremnine za zaposlenike na određeno vrijeme koji na nju prije nisu imali pravo. Namjera ove mjere bila je da se odvrati poslodavce od zapošljavanja radnika na ugovore na određeno vrijeme. To je potaknulo zapošljavanje na neodređeno vrijeme, ali i rad na temelju ugovora o djelu. 


\section{Španjolska}

U slučaju otkaza zbog ekonomskih razloga $\mathrm{i} / \mathrm{ili}$ restrukturiranja, otpremnina je u iznosi plaće za 20 dana po godini staža rada i maksimalno 12 mjesečnih plaća. Radnik koji dobije otkaz iz disciplinskih razloga nema pravo na otpremninu. U slučaju da poslodavac prizna kako je stegovni otkaz neopravdan, ugovor o radu se raskida s danom otkaza, ali poslodavac mora zaposleniku platiti naknadu za neopravdani otkaz koja je jednaka plaći za 33 dana rada za svaku godinu radnog staža do najvišeg iznosa koji odgovara plaći za 24 mjeseca. U tvrtkama koje imaju manje od 25 zaposlenih, Javni fond za naknadu plaća (španj. Fondo de Garantía Salarial) isplaćuje $40 \%$ predviđenog zakonskog iznosa u slučaju kolektivnog otkaza (ako je unutar 90 dana bez posla ostalo svih 5 zaposlenika u mikrotvrtkama, najmanje 10 radnika u tvrtkama do $100 \mathrm{za}-$ poslenih; $10 \%$ radnika u tvrtkama s od 100 do 299 zaposlenih i najmanje 30 radnika u tvrtkama s više od 299 zaposlenih).

\section{Švedska}

Ne postoji zakonsko određenje o uvjetima i iznosu otpremnine, ali to se može regulirati kolektivnim ugovorima.

\section{ZAKLJUČAK}

Prilično je nejasno ili barem nedovoljno istraženo kako sustav otpremnina utječe na zapošljavanje, nezaposlenost, fleksibilnost tržišta rada i mobilnost radne snage. Iako su razlike u određivanju prava na otpremninu u promatranim zemljama gotovo veće nego sličnosti, ipak se mogu donijeti određeni zaključci. Kao prvo, jasan je stabilan i značajan negativni odnos između ekonomskog učinka mjerenog prema BDP-u po stanovniku i izdašnosti prava na otpremnine - bogatije i razvijenije zemlje pokazuju tendenciju razmjerno nižih iznosa otpremnina u usporedbi sa siromašnijim i manje razvijenima. Uz to, moguće je utvrditi kako je postojanje obvezujućih sustava otpremnine na nacionalnoj razini mnogo slabije u visokorazvijenim gospodarstvima. To je uglavnom u skladu s povijesnom ulogom nacionalnih sustava otpremnina, kao preteče širih intervencija politike zaštite za vrijeme nezaposlenosti.

Slijedom navedenog, kao drugo, javlja se jasna negativna povezanost između izdašnosti prava na otpremnine i naknada za nezaposlene. To potvrđuje kako je osiguranje od nezaposlenosti u najvećoj mjeri preuzelo ulogu nacionalnih sustava otpremnina kod zaštite radnika od posljedica gubitka posla. Ovo poziva na potrebu kritičkog preispitivanja postojećih nacionalnih sustava otpremnina u pogledu njihove dostupnosti i adekvatnosti, pogotovo ako se isti rizik pokriva s dva paralelna sustava socijalnih primanja. Treće, značajni kaskadni učinak vrijednosti otpremnine koji se ostvaruje ako je zaposlenik duži niz godina kod istog poslodavca, gotovo sigurno smanjuje pokretljivost radne snage i negativno utječe na restrukturiranje gospodarstva, ali promiče stabilnost veze poslodavaca s radnicima (lojalnost) koja može imati pozitivne učinke. Konačno, kao četvrto, očituje se pozitivan i značajan utjecaj izdašnosti mirovinskih prava na prihvaćanje otpremnine. Čini se kako u tom području postoji komplementarna funkcija nacionalnih sustava otpremnina i javnih mirovinskih sustava. Očekivana pristojna mirovina motivira starije radnike, koji imaju ili će uskoro imati uvjete za mirovinu, na (prijevremeno) umirovljenje, a time i prihvaćanje otpremnine. Konačno, različiti tretmani prekida ugovornog odnosa sklopljenog na određeno i neodređeno vrijeme mogu dodatno naglasiti segmentaciju tržišta rada na zaštićene i nezaštićene, ali, s druge strane, pokušaji njihova približavanja (premda s više pozitivnih nego negativnih strana), ne moraju uvijek dati priželjkivane rezultate.

Priredio: Predrag Bejaković

Institut za javne financije 